\title{
Land application of spent gypsum from ditch filters: phosphorus source or sink?
}

\author{
Karen L. Grubb ${ }^{1}$, Joshua M. McGrath ${ }^{2}$, Chad J. Penn ${ }^{3}$, Ray B. Bryant ${ }^{4}$ \\ ${ }^{1}$ USDA-National Institute of Food and Agriculture, Washington, D.C., USA; \\ ${ }^{2}$ Department of Environmental Science and Technology, University of Maryland, College Park, PA, USA; Corresponding Author: \\ mcgrathj@umd.edu \\ ${ }^{3}$ Department of Plant and Soil Sciences, Oklahoma State University, Stillwater, USA; \\ ${ }^{4}$ USDA-Agricultural Research Service, College Park, PA, USA.
}

Received 26 May 2011; revised 13 July 2011; accepted 29 July 2011.

\begin{abstract}
Agricultural drainage ditches can provide a direct connection between fields and surface waters, and some have been shown to deliver high loads of phosphorus $(P)$ to sensitive water bodies. A potential way to reduce nutrient loads in drainage ditches is to install filter structures containing $P$ sorbing materials (PSMs) such as gypsum to remove $P$ from ditch flow. The objective of this study was to determine the effect of land-application of gypsum removed from such filters on soil $P$ forms and concentrations. Gypsum was saturated at two levels on a mass basis of $\mathbf{P}$ and applied to two soils of contrasting texture, a silt loam and a sandy loam and applied at both a high and low rate. The treated soils were incubated in the laboratory at $25^{\circ} \mathrm{C}$, and samples were collected at 1, 7 and 119 days after initiation. Soil type, time after application, gypsum rate, and $P$ saturation level all had a significant impact on soil $P$ forms and concentrations. However, it appears that land application of spent filter gypsum at realistic rates would have little effect on soluble $P$ concentrations in amended soils.
\end{abstract}

Keywords: Phosphorus Sorbing Materials; Gypsum; Ditch Filter

\footnotetext{
Abreviations: BMP, Best Management Practices; ICP-OES, Inductively Coupled Plasma-Optical Emission Spectroscopy; LG, Low Gypsum Rate; HG, High Gypsum Rate; LP, Low P Saturation Level; HP, High P Saturation Level; FGD, Flue-Gas Desulfurization; PSM, Phosphorus Sorbing Material
}

\section{INTRODUCTION}

Globally, phosphorus (P) and nitrogen (N) loading to surface water contribute to accelerated eutrophication, resulting in water quality degradation. The Chesapeake Bay is the largest estuary in the United States and has been declared a "National Treasure" by a White House Executive Order [1]. However, the water quality of the Chesapeake Bay has been significantly impaired due to sediment and nutrient contributions from point and nonpoint sources. The Chesapeake Bay Program Phase 4.3 Watershed Model 2007 Simulation estimates that 3756 $\mathrm{mg}$ of $\mathrm{P}$ or $45 \%$ of the total $\mathrm{P}$ load delivered to the Chesapeake Bay in 2007 originated from agriculture [2]. The Delmarva Peninsula is located on the eastern shore of the Bay and is home to a large concentration of poultry production; leading to a regional surplus of P. Many of the soils surrounding the poultry producing areas of the Peninsula have become saturated with $\mathrm{P}$ after longterm $\mathrm{P}$ application beyond crop requirements [3].

The southern Delmarva Peninsula is dominated by coarse textured soils and shallow groundwater tables. Agricultural drainage ditches dominate the landscape and are used to move water away from the rooting zone in order to allow crop production. These conditions contribute to $\mathrm{P}$ movement through subsurface pathways to ditches and ultimately surface water and the Chesapeake Bay [4-6]. Vadas et al. [7] found that environmentally significant concentrations of $\mathrm{N}$ and $\mathrm{P}$ moved to ditch waters from soils with high $\mathrm{P}$ concentrations and shallow groundwater. This rapid lateral movement of $\mathrm{P}$ through shallow subsurface pathways represents a bypass of most traditional best management practices (BMP's) designed for P control, which typically focus on overland transport of dissolved and sediment bound $\mathrm{P}$. Recently, research has been conducted on passive P filters which can be installed in agricultural drainage 
ditches and used to capture dissolved $\mathrm{P}$ once it reappears in the ditch [8]. These structures use head pressure generated by elevation or flow control devices to force ditch water through a P sorbing material (PSM). Often these PSM's are byproducts of other industrial processes and they provide a substrate for precipitation with metals and/or adsorption onto metal oxides or hydroxides [9-11]. Phosphorus sorbing materials can be applied directly to soil or manure, broadcast into ditches, or used in flowthrough structures [12]. One readily available PSM is byproduct gypsum, typically produced through flue-gas desulfurization (FGD) at coal-fired power plants. The primary mode of action of byproduct gypsum is dissolution of the $\mathrm{CaSO}_{4}$ and precipitation of calcium phosphates from dissolved Ca in solution [13]. Several PSM filters are in place and being evaluated on the Delmarva Peninsula to determine their efficiency as a potential BMP in these landscapes. Therefore there is a need to determine how to handle the residual PSM's after the filters either physically or chemically fail. The benefits of soil amendment with gypsum are well known. Gypsum has been shown to improve soil physical properties by alleviating surface crusting and compaction, increasing water infiltration and holding capacity, improving aggregate stability, and reducing water runoff and erosion [14]. However, there is a need to determine how $\mathrm{P}$ applied with gypsum residuals from PSM filters will behave in regards to soil $\mathrm{P}$ availability. Therefore, a laboratory incubation study was conducted to evaluate soil application of spent gypsum from a ditch filter. The objective of this study was to determine how spent gypsum application would affect soil P forms and concentrations over time.

\section{MATERIALS AND METHODS}

\subsection{Soil Incubation Study}

A soil incubation study was initiated to determine and compare the effect of adding phosphorus saturated flue gas desulfurization gypsum $\left(\mathrm{CaSO}_{4} \cdot 2 \mathrm{H}_{2} \mathrm{O}\right)$ on soil chemical properties. Treatments consisted of two soil types (silt loam and sandy loam), two gypsum rates (high rate and low rate), and two P saturation levels (25\% and $75 \%$ of the gypsum sorption maximum; see below for details), and sampled at three dates. The treatments were assigned in a two (soil type) by two (gypsum rate) by two (P saturation level) by three (sampling date) factorial design, resulting in 24 treatment combinations. Total $\mathrm{P}$ was only extracted at two sampling dates (day 1 and 119), while the sequential $\mathrm{P}$ fractionation was performed at day 1, 7 and 119. Each treatment combination was randomly assigned within four replicate incubators, with each incubator serving as one block. The incubators used were VWR Scientific Model 2020 Low Temperature Incubators set at $25^{\circ} \mathrm{C}$.

Soils used in the study were collected to a depth of 30 $\mathrm{cm}$ from cropped fields located on the Delmarva Peninsula. The sandy loam was a Galestown siliceous, mesic Psammentic Hapludult located in Quantico, MD, USA that was planted in corn when collected. The silt loam was a Mattapex fine-silty, mixed, active, mesic Aquic Hapludult and was collected from the edge of cultivated field located in Chestertown, MD, USA planted in soybeans when collected. The soils were air-dried at $20^{\circ} \mathrm{C}$, passed through a $20-\mathrm{mm}$ wire screen (to remove detritus), and then $200 \mathrm{~g}$ (dry weight) of soil was added to 96 plastic cups. Each cup had a snap cap with four $3.97 \mathrm{~mm}$ holes drilled in the lid to allow for air exchange. Prior to amendment, a pre-incubation was conducted where each cup was brought to a moisture content equivalent to $70 \%$ of field capacity and incubated at $25^{\circ} \mathrm{C}$ for 14 days. Field capacity was determined by the method of Tan [15].

The FGD gypsum was collected from US Gypsum Company in Baltimore. In order to determine the amount of $\mathrm{P}$ to add to the gypsum for the incubation study, $\mathrm{P}$ sorption isotherms were conducted. Gypsum was airdried and sieved $(2 \mathrm{~mm})$ and $2 \mathrm{~g}$ of sample was weighed into $50 \mathrm{ml}$ centrifuge tubes. Phosphorus solutions were made at 12 concentrations $(0,1,5,10,50,100,800$, 1600, 2400, 3200, 6400, 10,000 mg P/L) using $\mathrm{KH}_{2} \mathrm{PO}_{4}$ and deionized water. Four tubes with gypsum were amended with $30 \mathrm{ml}$ of solution at each concentration for a total of 48 tubes. The P solution and gypsum were reacted in an end-over-end shaker for 24 hours, then centrifuged at $1163 \times \mathrm{G}$, and filtered through $0.45 \mu \mathrm{m}$ filters. The supernatant was analyzed for total dissolved $\mathrm{P}$ using inductively coupled plasma-optical emission spectroscopy (ICP-OES). This $\mathrm{P}$ addition process was repeated three more times on the same sample to determine sequential $\mathrm{P}$ sorption. A cumulative sorption curve was created by plotting the sum of $\mathrm{P}$ adsorbed during the four sequential sorption experiments versus the initial $\mathrm{P}$ concentration in solution. The point at which the cumulative curve leveled off (i.e. slope $=0$ ) was assumed to represent the potential sorption maximum. At the sorption maximum, approximately $24.7 \mathrm{mg} \cdot \mathrm{g}^{-1}$ of $\mathrm{P}$ was sorbed. The amount of P sorbed at 25 and $75 \%$ of this maximum was approximated at 6.25 and $18.75 \mathrm{mg} \cdot \mathrm{g}^{-1}$, requiring initial $\mathrm{P}$ concentrations of 550 and 1550 $\mathrm{mg} \cdot \mathrm{L}^{-1}$.

In order to partially saturate the gypsum at the target 25 and $75 \%$ levels, $200 \mathrm{~g}$ of gypsum was reacted for 24 hours with either $2.27 \mathrm{~L}$ of $550 \mathrm{mg} \cdot \mathrm{L}^{-1}$ or $2.42 \mathrm{~L}$ of 1550 $\mathrm{mg} \cdot \mathrm{L}^{-1} \mathrm{P}$ solution, respectively. After the reactions were complete, the excess solution was poured off and the 
gypsum was allowed to air dry. After completion of the pre-incubation, each cup was amended with either $0.5 \mathrm{~g}$ or $2.0 \mathrm{~g}$ in order to approximate a total application rate of 5.6 or $22.4 \mathrm{Mg} \cdot \mathrm{ha}^{-1}$ gypsum, assuming $2244 \mathrm{Mg} \cdot \mathrm{ha}^{-1}$ of soil. The two levels of $\mathrm{P}$ saturation and two rates of gypsum resulted in four treatment combinations: low $\mathrm{P}$ and low gypsum (LP-LG), high P and low gypsum (HPLG), low $\mathrm{P}$ and high gypsum (LP-HG), and high $\mathrm{P}$ and high gypsum (HP-HG). The resulting $\mathrm{P}$ and $\mathrm{Ca}$ application rates associated with each treatment combination are presented in Table 1. In addition, unamended control samples were included in the study, but were not compared statistically to the amended soils because they would have caused an unbalanced design, complicating statistical analysis. During the incubation study, samples were weighed every 7 days, and sufficient deionized water was added to maintain the moisture content at $70 \%$ of field capacity. Cups were destructively sampled 1,7 , and 119 days after amendment. When removed, samples were oven dried at $60^{\circ} \mathrm{C}$ for 24 hours and sieved using a 2-mm sieve prior to sample analysis. Samples from day 1, 7, and 119 were analyzed for chemically defined $\mathrm{P}$ fractions and total $\mathrm{P}$ and $\mathrm{Ca}$ concentrations were determined in samples from day 1 and 119 using methods presented below.

\subsection{Laboratory Analyses}

Samples from day 1, 7, and 119 were extracted using the phosphorus fractionation method modified from Hedley et al. [16] by Warren et al. [17]. Samples were extracted sequentially by deionized $\mathrm{H}_{2} \mathrm{O}, 0.5 \mathrm{M}$ Na$\mathrm{HCO}_{3}, 0.1 \mathrm{M} \mathrm{NaOH}$, and $1.0 \mathrm{M} \mathrm{HCl}$ at a solid to solution ratio of 1:60 (0.5 g to $30 \mathrm{ml})$. Samples $(0.5 \mathrm{~g})$ were weighed into $50 \mathrm{ml}$ centrifuge tubes and equilibrated for $24 \mathrm{~h}$ with $30 \mathrm{ml}$ of the respective extractant at low speed on a reciprocating shaker. After shaking, samples were centrifuged for 15 minutes at $1538 \times G$. The supernatant was passed through a $0.45 \mu \mathrm{m}$ Millipore filter, diluted tenfold with deionized $\mathrm{H}_{2} \mathrm{O}$, and analyzed for $\mathrm{P}$ using ICP-OES. The Hedley fraction separates $\mathrm{P}$ into chemically defined pools. Typically the $\mathrm{H}_{2} \mathrm{O}-\mathrm{P}$ is defined as labile $\mathrm{P}$,

Table 1. Phosphorus (P) and calcium (Ca) application rates associated with each $\mathrm{P}$ saturation and gypsum treatment combination.

\begin{tabular}{|c|c|c|c|c|}
\hline $\begin{array}{l}\text { Treatment } \\
\text { Combination }\end{array}$ & $\begin{array}{c}\text { P Saturation } \\
\text { Level }\end{array}$ & $\begin{array}{l}\text { Gypsum Appli- } \\
\text { cation Rate }\end{array}$ & $\begin{array}{c}\text { P Applica- } \\
\text { tion Rate }\end{array}$ & $\begin{array}{c}\text { Ca Applica- } \\
\text { tion Rate }\end{array}$ \\
\hline & $\begin{array}{l}\text { \% of maxi- } \\
\text { mum }\end{array}$ & $\mathrm{Mg} \cdot \mathrm{ha}^{-1}$ & \multicolumn{2}{|c|}{$\mathrm{kg} \cdot \mathrm{ha}^{-1}$} \\
\hline LP-LG & $25 \%$ & 5.6 & 35 & 1232 \\
\hline HP-LG & $75 \%$ & 22.4 & 105 & 1232 \\
\hline LP-HG & $25 \%$ & 5.6 & 140 & 4928 \\
\hline HP-HG & $75 \%$ & 22.4 & 420 & 4928 \\
\hline
\end{tabular}

$\mathrm{NaHCO}_{3}-\mathrm{P}$ represents $\mathrm{P}$ loosely bound by $\mathrm{Ca}, \mathrm{Fe}, \mathrm{Al}$, or organics, $\mathrm{NaOH}$ extracts $\mathrm{Fe}$ and Al-P or $\mathrm{P}$ associated with humic compounds, and the $\mathrm{HCl}$ fraction represents Ca-P, P held in internal structures, or tightly held $\mathrm{P}$ in organic forms such as phytate-P.

Total $\mathrm{P}$ was determined in soil samples from days 1 and 119 using EPA method 200.2 [18]. Soil (0.5 g) was digested using an Environmental Express hot block model SC154 with $2 \mathrm{ml}$ of $1: 1 \mathrm{HNO}_{3}$ and $5 \mathrm{ml}$ of 1:4 $\mathrm{HCl}$ at $95^{\circ} \mathrm{C}$. The samples were removed from the hot block after 30 minutes, cooled, and diluted to $50 \mathrm{ml}$ total volume using deionized $\mathrm{H}_{2} \mathrm{O}$ and analyzed using the ICP-OES. Soil $\mathrm{pH}$ was determined in each sample via $\mathrm{pH}$ probe using $10 \mathrm{~g}$ of air-dried soil and $10 \mathrm{ml}$ of deionized $\mathrm{H}_{2} \mathrm{O}$.

\subsection{Statistical Analysis}

Statistics were conducted using SAS version 9.1. Although the experimental design was a randomized incomplete block design, the results were analyzed as a randomized complete block design (background samples were not considered in statistical analysis, but were indicated as comparisons). Incubators served as blocks, and the blocks were treated as a random factor. Proc mixed was used as the data analysis model. Tukey's Multiple Mean Comparison Test was used to make pair wise comparisons [19]. Significant differences in means were determined at $\alpha<0.05$. Due to the complex factorial design of the experiment with treatment factors of gypsum rate, $\mathrm{P}$ saturation, soil type, and time interactions between factors prohibited evaluation of the main effect of treatment factors in most cases. However, wherever a variable was determined to be significantly affected by a treatment factor or multiple factor interaction the means for the other variables (even if they were not significantly affected) are presented for the sake of comparison.

\section{RESULTS AND DISCUSSION}

Soil type, time of incubation, gypsum rate, and $P$ saturation level of the gypsum were the main treatment factors evaluated. The complex interactions between soil, gypsum, and $\mathrm{P}$ chemistry over time made statistical analysis of the data complex. However, several clear trends emerged from the data.

\subsection{Effect of Soil Type on Soil P Forms in Unamended Soil: Silt Loam Had Higher $P$ Concentrations in Each Fraction Except for $\mathrm{H}_{2} \mathrm{O}$}

The control soils, which were not amended with gypsum or $\mathrm{P}$, were considered separately during statistical 
Table 2. Mean pH, phosphorus concentrations in chemically defined fractions, the cumulative extracted phosphorus from the sequential extraction, and total phosphorus and calcium extracted by soil type averaged across incubation time for unamended soils*

\begin{tabular}{ccccccccc}
\hline Soil Type & $\mathrm{pH}$ & $\mathrm{H}_{2} \mathrm{O}$ & $\mathrm{NaHCO}_{3}$ & $\mathrm{NaOH}$ & $\mathrm{HCl}$ & Cumulative Extracted & Total P & Total Ca \\
\hline & - & $\mathrm{mg} \cdot \mathrm{kg}^{-1}$ & $\mathrm{mg} \cdot \mathrm{kg}^{-1}$ & $\mathrm{mg} \cdot \mathrm{kg}^{-1}$ & $\mathrm{mg} \cdot \mathrm{kg}^{-1}$ & $\mathrm{mg} \cdot \mathrm{kg}^{-1}$ & $\mathrm{mg} \cdot \mathrm{kg}^{-1}$ & $\mathrm{mg} \cdot \mathrm{kg}^{-1}$ \\
sandy loam & 4.39 & $11.23 \mathrm{a}$ & $23.73 \mathrm{~b}$ & $46.30 \mathrm{~b}$ & $11.81 \mathrm{~b}$ & $93.06 \mathrm{~b}$ & 180.21 & 229.65 \\
silt loam & 6.26 & $8.59 \mathrm{~b}$ & $42.46 \mathrm{a}$ & $127.77 \mathrm{a}$ & $42.19 \mathrm{a}$ & $221.01 \mathrm{a}$ & 412.71 & 1583.88 \\
\hline
\end{tabular}

*Means followed by different letters within the same column are significantly different at $P<0.05$. Means not followed by a letter could not be compared statistically due to a significant interaction $(P<0.05)$ between the main effects of soil type and time.

Table 3. Mean $\mathrm{pH}$, phosphorus $(\mathrm{P})$ concentrations in chemically defined fractions, the cumulative extracted phosphorus from the sequential extraction, and total phosphorus and calcium extracted for the two-way interaction between soil type and day in unamended soils*.

\begin{tabular}{|c|c|c|c|c|c|c|c|c|c|}
\hline Soil Type & Day & $\mathrm{pH}$ & $\mathrm{H}_{2} \mathrm{O}$ & $\mathrm{NaHCO}_{3}$ & $\mathrm{NaOH}$ & $\mathrm{HCl}$ & Cumulative Extracted & Total P & Total Ca \\
\hline & - & - & $\mathrm{mg} \cdot \mathrm{kg}^{-1}$ & $\mathrm{mg} \cdot \mathrm{kg}^{-1}$ & $\mathrm{mg} \cdot \mathrm{kg}^{-1}$ & $\mathrm{mg} \cdot \mathrm{kg}^{-1}$ & $\mathrm{mg} \cdot \mathrm{kg}^{-1}$ & $\mathrm{mg} \cdot \mathrm{kg}^{-1}$ & $\mathrm{mg} \cdot \mathrm{kg}^{-1}$ \\
\hline sandy loam & 1 & $4.55 b$ & 10.68 & 21.29 & 45.19 & 12.57 & 89.73 & $199.25 c$ & $260.88 b$ \\
\hline sandy loam & 7 & $4.44 \mathrm{~b}$ & 10.16 & 20.50 & 45.17 & 10.23 & 86.05 & $\mathrm{Nd}^{* *}$ & nd \\
\hline sandy loam & 119 & $4.18 \mathrm{c}$ & 12.84 & 29.40 & 48.53 & 12.62 & 103.39 & $161.18 \mathrm{c}$ & $198.43 b$ \\
\hline silt loam & 1 & $6.29 a$ & 8.81 & 41.40 & 127.72 & 53.00 & 230.92 & $367.78 b$ & $1544.25 \mathrm{a}$ \\
\hline silt loam & 7 & $6.27 \mathrm{a}$ & 8.99 & 45.96 & 126.15 & 39.55 & 220.65 & nd & nd \\
\hline silt loam & 119 & $6.22 \mathrm{a}$ & 7.97 & 40.03 & 129.46 & 34.02 & 211.48 & $457.65 a$ & $1623.50 \mathrm{a}$ \\
\hline
\end{tabular}

*Means followed by different letters within the same column are significantly different at $P<0.05$. Means not followed by a letter were determined to not have a significant interaction between soil type and time; **No data (nd) was available for day seven total phosphorus or calcium concentrations.

analysis. There were four replications or blocks of each unamended soil included in the study. However, in order to balance the design we would have had to include two levels of zero gypsum and two levels of P saturation of the gypsum or we would have had to include a gypsum only treatment (no P) and P only treatment (no gypsum). The size of the incubators available precluded these treatment options; therefore, in order to keep the experiment balanced for statistical analysis the unamended soils were considered separately and presented only for comparison. Only the main effect of soil type was determined to be significant for $\mathrm{H}_{2} \mathrm{O}-\mathrm{P}, \mathrm{NaHCO}_{3}-\mathrm{P}, \mathrm{NaOH}-$ $\mathrm{P}$, HCl-P, and cumulative $\mathrm{P}$ extracted in the sequential fractionation. Therefore the mean concentration of each of these variables is presented across incubation time in Table 2. The silt loam soil had significantly higher $\mathrm{P}$ concentrations than the sandy loam in each fraction except for $\mathrm{H}_{2} \mathrm{O}$. These results indicate that the silt loam, while it had higher overall $\mathrm{P}$ concentrations, had a higher $P$ buffer capacity than the sandy loam, resulting in higher $\mathrm{H}_{2} \mathrm{O}$-extractable $\mathrm{P}$ in the sandy loam than the silt loam. This trend persisted through most of the gypsum-P treatments discussed later.

\subsection{Effect of Soil Type and Incubation Time on Total Soil Phosphorus and Calcium and $\mathrm{pH}$ in Unamended Soil}

There was a significant interaction between soil types and incubation time for the total P and Ca extracted by EPA method 200.2 [18]. Total P concentrations were significantly lower in the sandy loam samples than the silt loam for all sample dates (Table 3). Total P increased with time in the silt loam samples; however, these are unamended soils therefore no $\mathrm{P}$ was added over the course of the incubation. One possible explanation for this statistical increase would be loss of $\mathrm{C}$ through microbial respiration over time. The higher organic matter content of the silt loam compared to the sandy loam soil would explain why this increase in total $\mathrm{P}$ was not seen in the sandy loam samples. This mechanism of total $\mathrm{P}$ concentration increase via organic $C$ degradation has been observed among organic materials containing $\mathrm{P}$ [20].

\subsection{Main Effect of Soil Type on Amended Soil Phosphorus Forms: Soil Type Determined Differences in $\mathrm{NaHCO}_{3}$ and $\mathrm{HCl}$ Extractable Phosphorus}

Soil type did not interact with any other treatment factors (Table 4). The silt loam soil averaged across all gypsum and $\mathrm{P}$ application rates and incubation times had significantly more $\mathrm{NaHCO}_{3}-\mathrm{P}$ and $\mathrm{HCl}$ extractable $\mathrm{P}$ then the sandy loam soil. In addition, the cumulative $\mathrm{P}$ extracted through the sequential fractionation was sig- 
Table 4. Mean $\mathrm{pH}$, phosphorus concentrations in chemically defined fractions, the cumulative extracted phosphorus from the sequential extraction, and total phosphorus and calcium extracted for each main effect of day, phosphorus saturation, gypsum rate, or soil type in soils amended with gypsum and incubated for 119 days*.

\begin{tabular}{|c|c|c|c|c|c|c|c|c|}
\hline \multicolumn{9}{|c|}{ Sequential Extractions } \\
\hline & $\mathrm{pH}$ & $\mathrm{H}_{2} \mathrm{O}$ & $\mathrm{NaHCO}_{3}$ & $\mathrm{NaOH}$ & $\mathrm{HCl}$ & Cumulative Extracted & Total P & Total Ca \\
\hline & - & $\mathrm{mg} \cdot \mathrm{kg}^{-1}$ & $\mathrm{mg} \cdot \mathrm{kg}^{-1}$ & $\mathrm{mg} \cdot \mathrm{kg}^{-1}$ & $\mathrm{mg} \cdot \mathrm{kg}^{-1}$ & $\mathrm{mg} \cdot \mathrm{kg}^{-1}$ & $\mathrm{mg} \cdot \mathrm{kg}^{-1}$ & $\mathrm{mg} \cdot \mathrm{kg}^{-1}$ \\
\hline \multicolumn{9}{|c|}{ Incubation time } \\
\hline \multicolumn{9}{|l|}{ Days } \\
\hline 1 & 5.26 & $24.69 a$ & $45.40 \mathrm{~b}$ & 94.73 & 27.18 & $192.00 \mathrm{a}$ & 323.93 & 2544.71 \\
\hline 7 & 5.20 & $24.95 a$ & $50.14 a$ & 93.19 & 26.14 & $194.41 \mathrm{a}$ & & \\
\hline 119 & 5.21 & $16.46 \mathrm{~b}$ & $44.40 \mathrm{~b}$ & 98.72 & 23.75 & $183.32 b$ & 334.38 & 2086.85 \\
\hline \multicolumn{9}{|c|}{ Phosphorus Saturation } \\
\hline \multicolumn{9}{|l|}{$\%$} \\
\hline 25 & 5.23 & 14.26 & 40.97 & 92.21 & 24.92 & 172.36 & $318.98 b$ & 2206.98 \\
\hline 75 & 5.21 & 29.76 & 52.25 & 98.75 & 26.49 & 207.24 & $338.85 a$ & 2428.32 \\
\hline \multicolumn{9}{|l|}{ Gypsum Rate } \\
\hline \multicolumn{9}{|l|}{$\mathrm{Mg} \cdot \mathrm{ha}^{-1}$} \\
\hline 5.6 & 5.13 & 14.13 & 38.67 & 91.52 & 25.91 & 170.24 & $307.27 \mathrm{~b}$ & $1544.56 b$ \\
\hline 22.4 & 5.31 & 30.22 & 54.84 & 99.59 & 25.50 & 210.15 & $351.57 \mathrm{a}$ & $3119.26 a$ \\
\hline \multicolumn{9}{|l|}{$\underline{\text { Soil Type }}$} \\
\hline sandy loam & 4.29 & 27.64 & $34.91 b$ & 48.20 & $12.66 \mathrm{~b}$ & $123.41 \mathrm{~b}$ & 201.64 & 1656.45 \\
\hline silt loam & 6.13 & 16.66 & $58.18 \mathrm{a}$ & 141.84 & 38.49a & 255.17a & 452.52 & 2961.66 \\
\hline
\end{tabular}

*Means within a column, under the same main effect followed by different letters are significantly different at $P<0.05$. If no letter follows the mean no significance was determined or that treatment factor was involved in an interaction that prohibited statistical comparison.

nificantly higher in the silt loam soil than the sandy soil. The $\mathrm{NaHCO}_{3}$ fraction represents potentially labile $\mathrm{P}$ loosely held by $\mathrm{Fe}, \mathrm{Al}$, or in organic fractions. In comparison, the $\mathrm{HCl}$ fraction represents strongly held Ca-P, likely as phytate $\mathrm{P}$ or mineral $\mathrm{P}$ held in internal structures. The combination of gypsum and $\mathrm{P}$ did not signifycantly affect these $\mathrm{P}$ fractions in the soil. Instead these fractions were influenced by soil type. For each P-gypsum treatment combination each soil type was amended with the same amount of P; however, total P concentrations in the silt loam were much higher than the sandy loam as a result of the native soil $\mathrm{P}$ which overshadowed treatment effect. Total P concentrations in the sandy loam and silt loam soils prior to amendment were 180.21 and $412.71 \mathrm{mg} \cdot \mathrm{kg}^{-1}$, respectively.

\subsection{Effect of Soil Type, Gypsum Rate, and Phosphorus Saturation Level on Phosphorus Forms in Amended Soil: Phosphorus Application Rate and Soil Phosphorus Buffer Capacity Controlled Differences Expressed in $\mathrm{H}_{2} \mathrm{O}$ and $\mathrm{NaHCO}_{3}$ Extractable Phosphorus}

Soil type had a significant interaction with gypsum rate for the $\mathrm{H}_{2} \mathrm{O}-\mathrm{P}$ fraction $(P<0.05)$. Significantly more $\mathrm{H}_{2} \mathrm{O}-\mathrm{P}$ was extracted from both the sandy loam and silt loam soil amended at the highest gypsum rate of 22.4 $\mathrm{Mg} \cdot \mathrm{ha}^{-1}$ (HG) compared to their low gypsum rate counterparts (5.6 Mg $\cdot \mathrm{ha}^{-1}$; LG) within soil type (Table 5). In addition, the HG treated sandy loam had significantly higher $\mathrm{H}_{2} \mathrm{O}-\mathrm{P}$ than the $\mathrm{HG}$ silt loam treatment combination. At first it may seem counterintuitive that the high 
Table 5. Mean pH, phosphorus concentrations in chemically defined fractions, the cumulative extracted phosphorus from the sequential extraction, and total phosphorus and calcium extracted for the two-way interaction soil type and gypsum rate in soils amended with gypsum and incubated for 119 days*. $^{*}$.

\begin{tabular}{|c|c|c|c|c|c|c|c|c|c|}
\hline \multirow[b]{2}{*}{ Soil Type } & \multicolumn{8}{|c|}{ Sequential Extractions } & \multirow[b]{2}{*}{ Total Ca } \\
\hline & $\begin{array}{c}\text { Gypsum } \\
\text { Rate }\end{array}$ & $\mathrm{pH}$ & $\mathrm{H}_{2} \mathrm{O}$ & $\mathrm{NaHCO}_{3}$ & $\mathrm{NaOH}$ & $\mathrm{HCl}$ & $\begin{array}{l}\text { Cumulative } \\
\text { Extracted }\end{array}$ & Total P & \\
\hline & 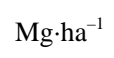 & - & $\mathrm{mg} \cdot \mathrm{kg}^{-1}$ & $\mathrm{mg} \cdot \mathrm{kg}^{-1}$ & $\mathrm{mg} \cdot \mathrm{kg}^{-1}$ & $\mathrm{mg} \cdot \mathrm{kg}^{-1}$ & $\mathrm{mg} \cdot \mathrm{kg}^{-1}$ & $\mathrm{mg} \cdot \mathrm{kg}^{-1}$ & $\mathrm{mg} \cdot \mathrm{kg}^{-1}$ \\
\hline sandy loam & 5.6 & $4.15 c$ & $16.39 \mathrm{bc}$ & 27.65 & 45.44 & 12.66 & 102.14 & 184.80 & 937.68 \\
\hline sandy loam & 22.4 & $4.45 b$ & 39.38a & 42.49 & 51.08 & 12.67 & 145.61 & 219.61 & 2423.13 \\
\hline silt loam & 5.6 & $6.11 \mathrm{a}$ & $11.88 \mathrm{c}$ & 49.68 & 137.61 & 39.17 & 238.34 & 429.74 & 2151.44 \\
\hline silt loam & 22.4 & $6.14 \mathrm{a}$ & $21.43 \mathrm{~b}$ & 66.68 & 146.07 & 37.80 & 271.99 & 475.29 & 3771.88 \\
\hline
\end{tabular}

* Means within a column followed by different letters are significantly different at $P<0.05$. If no letter follows the mean no significance was determined or that treatment factor was involved in an interaction that prohibited statistical comparison.

gypsum rates resulted in higher $\mathrm{H}_{2} \mathrm{O}$ extractable $\mathrm{P}$ concentrations, regardless of $\mathrm{P}$ saturation level. However, gypsum rate is tied directly to final $\mathrm{P}$ application rate. The LP-HG and HP-HG treatment combinations resulted in the two highest $P$ application rates of 140 and $420 \mathrm{~kg}$ $\mathrm{P} \cdot \mathrm{ha}^{-1}$, respectively (Table 1). By comparison the lower gypsum rate resulted in $\mathrm{P}$ application rates of 35 and 105 kg-P.ha ${ }^{-1}$ for the LP and HP saturation levels, respectively (Table 1). Therefore the increase in $\mathrm{H}_{2} \mathrm{O}-\mathrm{P}$ exhibited in each of the HG-soil combinations reflects the higher $\mathrm{P}$ application rates in combination with the $\mathrm{P}$ buffering capacity of the soil. The sandy loam has a lower $\mathrm{P}$ buffer capacity than the silt loam and therefore the $\mathrm{H}_{2} \mathrm{O}$ fraction in this soil is more susceptible to changes induced by $\mathrm{P}$ application at a given $\mathrm{P}$ rate. Similarly, there was a significant interaction between soil type and gypsum rate and this combination had significant effect on soil $\mathrm{pH}$. The $\mathrm{pH}$ of the silt loam soil was significantly higher than the $\mathrm{pH}$ of the sandy loam soils regardless of gypsum rate. Gypsum rate did not affect the $\mathrm{pH}$ of the silt loam soil, but the HG rate significantly increased soil $\mathrm{pH}$ compared to the $\mathrm{LG}$ rate. As with $\mathrm{H}_{2} \mathrm{O}-\mathrm{P}$ the sandy loam soil exhibited a lower $\mathrm{pH}$ buffer capacity and therefore was more easily affected by increased gypsum rate. Gypsum applications to soils considered more weathered (i.e. mineralogy dominated by $1: 1$ minerals and $\mathrm{Al} / \mathrm{Fe}$ oxyhydroxides) have been shown to increase in $\mathrm{pH}$ more than less weathered soils (i.e. mineralogy dominated by 2:1 minerals). This occurs mainly from a ligand exchange reaction of sulfate with terminal hydroxyl groups on variable charged minerals which releases a hydroxide to solution [21,22].

The effect of soil mineralogy and $\mathrm{P}$ buffer capacity is also demonstrated by the interaction between $\mathrm{P}$ saturation level and soil type, which was significant at $\mathrm{P}<0.05$. Averaged across time and gypsum rate the sandy loam$\mathrm{HP}$ treatment combination resulted in the highest $\mathrm{H}_{2} \mathrm{O}-\mathrm{P}$ concentration relative to the other treatments, which were all equivalent (Table 6). Once again the $\mathrm{P}$ saturation level cannot be separated from the total $\mathrm{P}$ amendment rate which was 105 and $420 \mathrm{~kg}-\mathrm{P} \cdot \mathrm{ha}^{-1}$ for the HPLG and HP-HG treatment combinations respectively. Therefore, only at the highest $\mathrm{P}$ application rate, on the least buffered soil was there a significant effect of soil type-P saturation. It is interesting to note that a different trend was seen in $\mathrm{NaHCO}_{3}-\mathrm{P}$ for the soil-P saturation treatment combination (Table 6). There were no statistical differences between the sandy loam soil and HP or LP treatments, which had less $\mathrm{NaHCO}_{3}-\mathrm{P}$ than either silt loam combination. However, the HP-silt loam combination resulted in higher $\mathrm{NaHCO}_{3}-\mathrm{P}$ concentrations than the LP-silt loam combination. This is likely a result of the higher clay and silt content of the silt loam soil retaining more of the added $\mathrm{P}$ in this fraction than in the sandy loam where the added $\mathrm{P}$ resided in the $\mathrm{H}_{2} \mathrm{O}$ extractable fraction.

\subsection{Effect of Soil Type and Time on Total Phosphorus and Calcium and $\mathrm{pH}$ in Amended Soils}

Soil type also had a significant interaction $(\mathrm{P}<0.05)$ with incubation time for both total extractable $\mathrm{P}$ and $\mathrm{Ca}$ (determined by EPA method 200.2) and soil pH. Total extractable P was significantly higher on day 119 (471 $\mathrm{mg} \cdot \mathrm{kg}^{-1}$ ) in the silt loam soil than on day one (434 $\mathrm{mg} \cdot \mathrm{kg}^{-1}$ ) and the silt loam soils had more total P on either day than the sandy loam on either day (Table 7). However, there was no statistical difference between the sandy loam soil on day $1\left(214 \mathrm{mg} \cdot \mathrm{kg}^{-1}\right)$ and day 119 $\left(189 \mathrm{mg} \cdot \mathrm{kg}^{-1}\right)$. No additional $\mathrm{P}$ was added during the incubation so the increase in total $\mathrm{P}$ seen in the silt loam soil is likely due to loss of $\mathrm{C}$ through microbial respiretion as previously discussed with the unamended soils. This loss would be expected to be more pronounced in 
Table 6. Mean $\mathrm{pH}$, phosphorus concentrations in chemically defined fractions, the cumulative extracted phosphorus from the sequential extraction, and total phosphorus and calcium extracted for the two-way interaction soil type and phosphorus saturation level in soils amended with gypsum and incubated for 119 days*.

\begin{tabular}{|c|c|c|c|c|c|c|c|c|c|}
\hline \multicolumn{10}{|c|}{ Sequential Extractions } \\
\hline Soil Type & $\begin{array}{l}\text { Phosphorus } \\
\text { Saturation }\end{array}$ & $\mathrm{pH}$ & $\mathrm{H}_{2} \mathrm{O}$ & $\mathrm{NaHCO}_{3}$ & $\mathrm{NaOH}$ & $\mathrm{HCl}$ & $\begin{array}{l}\text { Cumulative } \\
\text { Extracted }\end{array}$ & Total P & Total Ca \\
\hline & $\%$ & - & $\mathrm{mg} \cdot \mathrm{kg}^{-1}$ & $\mathrm{mg} \cdot \mathrm{kg}^{-1}$ & $\mathrm{mg} \cdot \mathrm{kg}^{-1}$ & $\mathrm{mg} \cdot \mathrm{kg}^{-1}$ & $\mathrm{mg} \cdot \mathrm{kg}^{-1}$ & $\mathrm{mg} \cdot \mathrm{kg}^{-1}$ & $\mathrm{mg} \cdot \mathrm{kg}^{-1}$ \\
\hline sandy loam & 25 & 4.31 & $17.35 b$ & $30.16 \mathrm{c}$ & 46.50 & 12.65 & 106.66 & 187.83 & 1640.03 \\
\hline sandy loam & 75 & 4.28 & $37.50 \mathrm{a}$ & $39.46 \mathrm{c}$ & 49.82 & 12.68 & 139.46 & 214.59 & 1671.83 \\
\hline silt loam & 25 & 6.11 & $11.30 \mathrm{~b}$ & $51.33 b$ & 136.01 & 36.68 & 235.31 & 441.93 & 2738.50 \\
\hline silt loam & 75 & 6.14 & $22.02 \mathrm{~b}$ & $65.04 a$ & 147.67 & 40.30 & 275.02 & 463.11 & 3184.81 \\
\hline
\end{tabular}

* Means within a column followed by different letters are significantly different at $P<0.05$. If no letter follows the mean no significance was determined or that treatment factor was involved in an interaction that prohibited statistical comparison.

Table 7. Mean $\mathrm{pH}$, phosphorus concentrations in chemically defined fractions, the cumulative extracted phosphorus from the sequential extraction, and total phosphorus and calcium extracted for the two-way interaction between soil type and incubation time in soils amended with gypsum and incubated for 119 days*.

\begin{tabular}{|c|c|c|c|c|c|c|c|c|c|}
\hline \multicolumn{10}{|c|}{ Sequential Extractions } \\
\hline Soil Type & Day & $\mathrm{pH}$ & $\mathrm{H}_{2} \mathrm{O}$ & $\mathrm{NaHCO}_{3}$ & $\mathrm{NaOH}$ & $\mathrm{HCl}$ & $\begin{array}{l}\text { Cumulative } \\
\text { Extracted }\end{array}$ & Total P & Total Ca \\
\hline & - & - & $\mathrm{mg} \cdot \mathrm{kg}^{-1}$ & $\mathrm{mg} \cdot \mathrm{kg}^{-1}$ & $\mathrm{mg} \cdot \mathrm{kg}^{-1}$ & $\mathrm{mg} \cdot \mathrm{kg}^{-1}$ & $\mathrm{mg} \cdot \mathrm{kg}^{-1}$ & $\mathrm{mg} \cdot \mathrm{kg}^{-1}$ & $\mathrm{mg} \cdot \mathrm{kg}^{-1}$ \\
\hline sandy loam & 1 & $4.39 \mathrm{~b}$ & 28.94 & 32.97 & 46.61 & 14.08 & 122.60 & $213.58 c$ & $2076.29 b$ \\
\hline sandy loam & 7 & $4.28 \mathrm{c}$ & 32.66 & 38.37 & 49.30 & 12.21 & 132.53 & $\mathrm{Nd}^{* *}$ & nd \\
\hline sandy loam & 119 & $4.20 \mathrm{~d}$ & 20.90 & 33.29 & 48.71 & 11.64 & 114.55 & 188.91c & $1208.61 c$ \\
\hline silt loam & 1 & $6.12 \mathrm{a}$ & 20.44 & 57.83 & 142.85 & 40.28 & 261.41 & $434.28 \mathrm{~b}$ & 3013.13a \\
\hline silt loam & 7 & 6.11a & 17.24 & 61.90 & 137.07 & 40.08 & 256.29 & nd & nd \\
\hline silt loam & 119 & $6.15 \mathrm{a}$ & 12.29 & 54.81 & 145.59 & 35.10 & 247.80 & $470.76 a$ & 2910.19a \\
\hline
\end{tabular}

*Means within a column followed by different letters are significantly different at $P<0.05$. If no letter follows the mean no significance was determined or that treatment factor was involved in an interaction that prohibited statistical comparison; **No data (nd) available as total phosphorus and calcium were only measured on day one and 119.

the silt loam soil due to higher organic matter content of the soil. Total Ca remained constant over time in the silt loam soil and was significantly higher than in the sandy loam soil at either date. However, total Ca concentrations decreased over time in the sandy loam soil. Therefore, it appears that gypsum application in the sandy loam caused the formation of recalcitrant $\mathrm{Ca}$ minerals after 119 days of incubation that were not extracted by the EPA 200.2 method. This is not surprising since this digestion method is less rigorous compared to the EPA 3050 digestion [23].

\subsection{Combined Effect of Soil Type, Gypsum Rate, and Incubation Time on $\mathrm{NaOH}$ Extractable Phosphorus: Increasing Gypsum Rate Decreased P Solubility}

The final significant effect of soil type was a three- way interaction with gypsum rate and time (i.e. day; Table 8). The combination of soil type, gypsum rate, and incubation time only had a significant effect on $\mathrm{NaOH}-\mathrm{P}$. Overall, the silt loam soil, for every gypsum rate and incubation time, had higher $\mathrm{NaOH}-\mathrm{P}$ concentrations than the sandy loam soil. Within the silt loam soil incubation time did not have a significant affect on NaOH-P concentrations at the LG rate. For the sandy loam at the LG rate, NaOH-P decreased significantly between day one and seven, and then stayed the same out to 119 days of incubation. At the HG rate the opposite trend was seen where $\mathrm{NaOH}-\mathrm{P}$ concentrations increased significantly from day one to seven and then remained the same out to 119 days of incubation. Figure 1 shows these trends alongside the control soils that were incubated without amendment, while statistical comparisons were not made 
Table 8. Mean pH, phosphorus concentrations in chemically defined fractions, the cumulative extracted phosphorus from the sequential extraction, and total phosphorus and calcium extracted for the three-way interaction between soil type, gypsum rate, and day in soils amended with gypsum*.

\begin{tabular}{|c|c|c|c|c|c|c|c|c|c|c|}
\hline \multirow[b]{2}{*}{ Soil Type } & \multirow[b]{2}{*}{$\begin{array}{l}\text { Gypsum } \\
\text { Rate }\end{array}$} & \multicolumn{9}{|c|}{ Sequential Extractions } \\
\hline & & Day & $\mathrm{pH}$ & $\mathrm{H}_{2} \mathrm{O}$ & $\mathrm{NaHCO}_{3}$ & $\mathrm{NaOH}^{\dagger}$ & $\mathrm{HCl}$ & $\begin{array}{c}\text { Cumulative } \\
\text { Extracted }\end{array}$ & Total P & Total Ca \\
\hline & $\mathrm{Mg} \cdot \mathrm{ha}^{-1}$ & - & - & $\mathrm{mg} \cdot \mathrm{kg}^{-1}$ & $\mathrm{mg} \cdot \mathrm{kg}^{-1}$ & $\mathrm{mg} \cdot \mathrm{kg}^{-1}$ & $\mathrm{mg} \cdot \mathrm{kg}^{-1}$ & $\mathrm{mg} \cdot \mathrm{kg}^{-1}$ & $\mathrm{mg} \cdot \mathrm{kg}^{-1}$ & $\mathrm{mg} \cdot \mathrm{kg}^{-1}$ \\
\hline sandy loam & 5.6 & 1 & 4.25 & 17.72 & 28.90 & $47.68 \mathrm{~d}$ & 14.73 & 109.03 & 204.10 & 1292.83 \\
\hline sandy loam & 5.6 & 7 & 4.14 & 19.43 & 28.32 & $44.87 \mathrm{e}$ & 12.03 & 104.66 & $\mathrm{Nd}^{* *}$ & nd \\
\hline sandy loam & 5.6 & 119 & 4.06 & 12.01 & 25.74 & $43.76 \mathrm{e}$ & 11.21 & 92.72 & 165.50 & 582.53 \\
\hline sandy loam & 22.4 & 1 & 4.54 & 40.16 & 37.04 & $45.54 \mathrm{e}$ & 13.42 & 136.17 & 223.06 & 2859.75 \\
\hline sandy loam & 22.4 & 7 & 4.43 & 45.88 & 48.42 & $53.73 c$ & 12.38 & 160.41 & nd & nd \\
\hline sandy loam & 22.4 & 119 & 4.36 & 31.06 & 41.92 & $53.72 \mathrm{c}$ & 12.13 & 139.49 & 215.66 & 1924.14 \\
\hline silt loam & 5.6 & 1 & 6.10 & 12.04 & 48.84 & $136.85 b$ & 40.72 & 238.45 & 410.04 & 2095.75 \\
\hline silt loam & 5.6 & 7 & 6.11 & 15.37 & 52.50 & $137.46 b$ & 41.29 & 246.62 & nd & nd \\
\hline silt loam & 5.6 & 119 & 6.13 & 8.25 & 47.70 & $138.50 \mathrm{~b}$ & 35.50 & 229.95 & 449.45 & 2207.13 \\
\hline silt loam & 22.4 & 1 & 6.13 & 28.85 & 66.83 & $148.86 a$ & 39.83 & 284.36 & 458.53 & 3930.50 \\
\hline silt loam & 22.4 & 7 & 6.11 & 19.12 & 71.30 & $136.68 b$ & 38.87 & 265.96 & nd & nd \\
\hline silt loam & 22.4 & 119 & 6.18 & 16.34 & 61.92 & 152.69a & 34.71 & 265.65 & 492.06 & 3613.25 \\
\hline
\end{tabular}

*The three way interaction for soil type, gypsum rate, and day was only found to be significant for the $\mathrm{NaOH}(P<0.05)$; Means for the other variables are given for reference. $* *$ No data (nd) available for total phosphorus or calcium on day seven.

between control soils and amended soils they are useful in interpreting the findings of the incubated soils relative to NaOH-P. With 7 to $1119 \mathrm{~d}$ of incubation, the high rate of gypsum application (HG) resulted in higher NaOH-P concentrations relative to the low rate (LG) applications for the sandy loam. This was also true after $119 \mathrm{~d}$ of incubation for the silt loam soil (Figure 1). These increases in $\mathrm{NaOH}-\mathrm{P}$ appear to be at the expense of a decrease in $\mathrm{H}_{2} \mathrm{O}-\mathrm{P}$ (Table 8). In other words, the greater $\mathrm{Ca}$ additions associated with the HG treatment (Table 1) are shifting $\mathrm{P}$ from the most soluble pool $\left(\mathrm{H}_{2} \mathrm{O}-\mathrm{P}\right)$ to a less soluble pool (NaOH-P), which is positive from the perspective of reducing risk of $\mathrm{P}$ loss to surface waters.

\subsection{Effect of Incubation Time on Soil Phosphorus Forms in Amended Soils: Added Phosphorus Became Less Available With Time}

Incubation time had a significant effect on all variables measured except HCl-P. As described previously time had a significant interaction with soil type for $\mathrm{pH}$, total $\mathrm{P}$, and total $\mathrm{Ca}$ and was part of the three way interaction that influenced $\mathrm{NaOH}-\mathrm{P}$ concentrations. In addition, incubation time had a significant effect on $\mathrm{H}_{2} \mathrm{O}$ and $\mathrm{NaHCO}_{3}$ extractable P concentrations without interacting with other treatment factors. Therefore the following results are presented as the main effect of time averaged across gypsum rate, $\mathrm{P}$ saturation level, and soil type. As shown in Table 4, $\mathrm{H}_{2} \mathrm{O}-\mathrm{P}$ concentrations did not change over the first seven days of incubation, but decreased thereafter. Initially, for all gypsum rate- $\mathrm{P}$ saturation combinations a large pool of highly soluble $\mathrm{P}$ was applied to each of the soils. It is not surprising that with time this $\mathrm{P}$ was repartitioned into the other soil $\mathrm{P}$ pools. Similarly, it is not surprising that time had no effect on $\mathrm{HCl}-\mathrm{P}$, even in combination with other treatment factors, as $\mathrm{HCl}$ would represent one of the most recalcitrant pools and therefore would be most resistant to change with time. Sodium bicarbonate extractable P showed a slight, but significant increase after seven days of incubation but then returned to its initial concentrations after 119 days. The slight increase after one week of incubation could be due to repartitioning of $\mathrm{P}$ as the system equilibrates. It is interesting to note that while time proved to be a significant factor for most variables measured in the amended soil it was not as important in the control soils that were incubated without added gypsum or $\mathrm{P}$. As discussed previously time only affected $\mathrm{pH}$ and total $\mathrm{P}$ and $\mathrm{Ca}$ in the unamended soils. This indicates that most of the $\mathrm{P}$ forms are relatively stable with time in these soils or in other words were in equilibrium relative to $\mathrm{P}$ forms and the addition of $\mathrm{P}$ with the spiked gypsum 


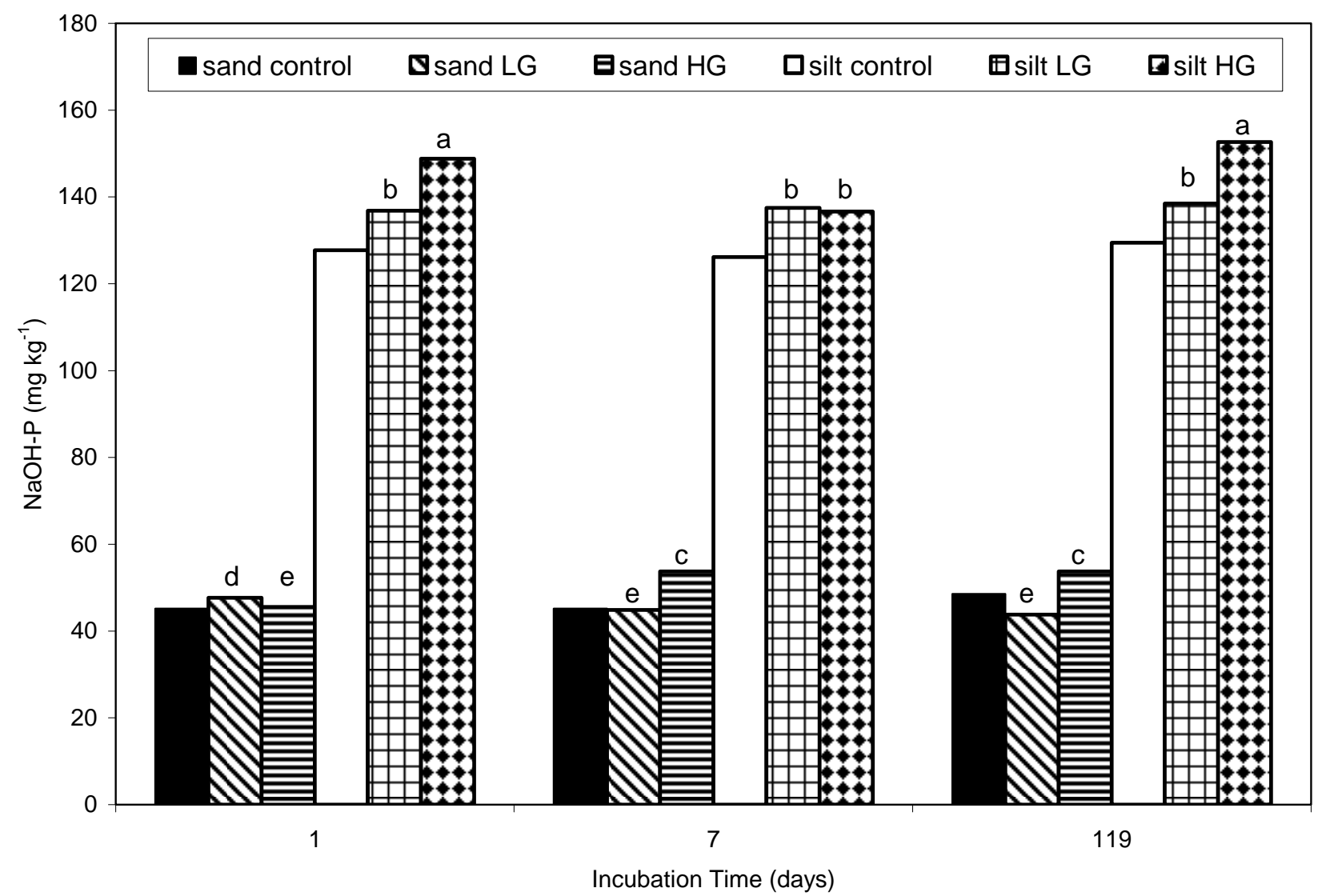

Figure 1. Effect of the combination of soil type, incubation time, and gypsum rate on sodium hydroxide extractable phosphorus concentrations in amended soils. Means labeled with different letters were considered statistically different $(P<0.05)$. Mean concentrations in unamended, control soils are presented for reference only and not included in statistical analysis.

caused changes to occur over time as this $\mathrm{P}$ was reallocated between the chemically defined fractions.

\subsection{Effect of Gypsum Rate and Phosphorus Saturation Level on Soil Phosphorus Forms: The Ratio of Phosphorus Added to Calcium Added Dominated Phosphorus Partitioning in the Soil}

The effects of gypsum rate and $\mathrm{P}$ saturation level were of the most interest to this study. As previously discussed gypsum rate interacted with soil type to significantly affect soil $\mathrm{pH}$ and $\mathrm{H}_{2} \mathrm{O}-\mathrm{P}$ and the three-way interaction between gypsum rate, soil type, and incubation time had a significant influence on $\mathrm{NaOH}-\mathrm{P}$. Likewise, $\mathrm{P}$ saturation level in combination with soil type significantly influenced $\mathrm{H}_{2} \mathrm{O}$ and $\mathrm{NaHCO}_{3}-\mathrm{P}$ concentrations.

As a main effect gypsum rate had a significant effect on total soil P. This is not surprising since $\mathrm{P}$ rate was tied directly to each gypsum rate. The LG rate corresponded with $\mathrm{P}$ application rates of either 35 or $105 \mathrm{~kg} \mathrm{P} / \mathrm{ha}$, while the HG rates resulted in application of 140 or 420 kg P/ha (Table 1). As a result, the HG rates resulted in an average of four times more $\mathrm{P}$ being applied. This crossed factorial of gypsum rate with $\mathrm{P}$ rate resulted in the HG treatments having significantly more total soil $\mathrm{P}$ averaged across soil type, incubation time, and $\mathrm{P}$ saturation level. The total P concentrations in soils amended with the LG and HG rates were 307.27 and $351.57 \mathrm{Mg}$ $\mathrm{P} /$ ha, respectively (Table 4). Similarly, the P saturation treatment factor was crossed with the resulting $\mathrm{P}$ application rate and had a significant main effect on total soil $\mathrm{P}$ concentrations. The LP treatment resulted in either 35 or $140 \mathrm{~kg} \mathrm{P} / \mathrm{ha}$ and the HP treatment represented P applications of either 105 or $420 \mathrm{~kg}$ P/ha (Table 1), or an average of three times more $\mathrm{P}$ being applied. As a result total soil P concentrations for the LP treatment, averaged across all other treatment factors, were $318.98 \mathrm{Mg} \cdot \mathrm{ha}^{-1}$ compared to $338.85 \mathrm{Mg} \cdot \mathrm{ha}^{-1}$ for the HP treatments. While $\mathrm{P}$ application rate was tied to gypsum rate and $\mathrm{P}$ saturation level, the Ca application rate was only tied to the gypsum rate and not confounded with $\mathrm{P}$ saturation level. Table 1 shows that the average total Ca rate for the LP and HP saturation levels was the same (3080 
Table 9. Mean pH, phosphorus concentrations in chemically defined fractions, the cumulative extracted phosphorus from the sequential extraction, and total phosphorus and calcium extracted for the two-way interaction of gypsum rate and phosphorus saturation in soils amended with gypsum*.

\begin{tabular}{|c|c|c|c|c|c|c|c|c|c|}
\hline \multirow[b]{2}{*}{ Gypsum Rate } & \multicolumn{8}{|c|}{ Sequential Extractions } & \multirow[b]{2}{*}{ Total Ca } \\
\hline & $\begin{array}{c}\text { Phosphorus } \\
\text { Saturation }\end{array}$ & $\mathrm{pH}$ & $\mathrm{H}_{2} \mathrm{O}$ & $\mathrm{NaHCO}_{3}$ & $\mathrm{NaOH}$ & $\mathrm{HCl}$ & $\begin{array}{c}\text { Cumulative } \\
\text { Extracted }\end{array}$ & Total P & \\
\hline $\mathrm{Mg} \cdot \mathrm{ha}^{-1}$ & $\%$ & - & $\mathrm{mg} \cdot \mathrm{kg}^{-1}$ & $\mathrm{mg} \cdot \mathrm{kg}^{-1}$ & $\mathrm{mg} \cdot \mathrm{kg}^{-1}$ & $\mathrm{mg} \cdot \mathrm{kg}^{-1}$ & $\mathrm{mg} \cdot \mathrm{kg}^{-1}$ & $\mathrm{mg} \cdot \mathrm{kg}^{-1}$ & $\mathrm{mg} \cdot \mathrm{kg}^{-1}$ \\
\hline 5.6 & 25 & 5.13 & $13.77 \mathrm{~b}$ & $36.53 c$ & $90.23 b$ & 25.18 & $165.72 b$ & 300.29 & 1480.72 \\
\hline 5.6 & 75 & 5.13 & $14.50 \mathrm{~b}$ & $40.80 \mathrm{bc}$ & $92.81 b$ & 26.64 & $174.76 \mathrm{~b}$ & 314.25 & 1608.39 \\
\hline 22.4 & 25 & 5.33 & $14.77 \mathrm{~b}$ & $45.60 \mathrm{~b}$ & $94.27 \mathrm{~b}$ & 24.64 & $179.28 b$ & 338.91 & 2981.67 \\
\hline 22.4 & 75 & 5.30 & $45.02 \mathrm{a}$ & $63.70 \mathrm{a}$ & 104.68a & 26.33 & 239.72a & 363.44 & 3248.25 \\
\hline \multicolumn{2}{|c|}{ Control $^{* *}$} & 5.32 & 9.91 & 33.10 & 87.03 & 27.00 & 157.04 & 296.46 & 906.76 \\
\hline
\end{tabular}

* Means within a column followed by different letters are significantly different at $P<0.05$. If no letter follows the mean no significance was determined or that treatment factor was involved in an interaction that prohibited statistical comparison; **Mean values for unamended soil averaged across incubation time and soil type are presented for reference only and not compared statistically to results for amended soils.

kg-Ca ha ${ }^{-1}$ ), but four times more Ca was applied with the HG rate than the LG rate. Therefore, total Ca concentration in soil amended at the HG rate was significantly higher than in soil amended at the LG rate, with soil Ca concentrations of 3119.26 and $1544.56 \mathrm{Mg} \mathrm{Ca} / \mathrm{ha}$, respectively.

As would be expected due to the crossed nature of the experimental design, where Ca rate and $\mathrm{P}$ rate were confounded within the $\mathrm{P}$ saturation and gypsum rate treatments, the interaction of $\mathrm{P}$ saturation and gypsum rate was significant. The four treatment factors resulting from this interaction represented four $\mathrm{P}$ rates and two $\mathrm{Ca}$ rates (Table 1) and had a significant effect on $\mathrm{H}_{2} \mathrm{O}$, $\mathrm{NaHCO}_{3}$, and $\mathrm{NaOH}$ extractable $\mathrm{P}$ as well as the cumulative $\mathrm{P}$ extracted through the sequential extraction. The HP-HG treatment, which represented the highest $\mathrm{P}$ application rate, resulted in significantly higher $\mathrm{H}_{2} \mathrm{O}$, Na$\mathrm{HCO}_{3}$, and $\mathrm{NaOH}$ extractable $\mathrm{P}$ as well as cumulative $\mathrm{P}$ concentrations than the other three treatment combinations (Table 9). The other three treatment combinations did not differ statistically for the $\mathrm{H}_{2} \mathrm{O}$ or $\mathrm{NaOH}$ fractions or the cumulative extractable P. However, the LP-HG treatment combination resulted in statistically higher $\mathrm{NaHCO}_{3}$ concentrations than the LP-LG treatment. The $\mathrm{NaHCO}_{3}$ fraction most closely reflected the $\mathrm{P}$ application rates of the four treatment combinations, so was apparently most responsive to $\mathrm{P}$ added with the spiked gypsum.

The $\mathrm{P}$ concentrations in each chemically defined fraction for the unamended soils (averaged across incubation time and soil type) are presented in Table 9 for reference. No statistical analysis was performed comparing the control soil to the amended soils; however, it is evident that only the highest $\mathrm{P}$ rate, which was delivered by the
HP-HG treatment, resulted in a substantial increase in any fraction relative to the control. Additionally, we see that the $\mathrm{HCl}$ fraction was unaffected by the $\mathrm{P}$ added with the gypsum. Overall, the HP-HG treatment increased cumulative $\mathrm{P}$ extracted by the sequential fractionation $53 \%$ relative to the control soils, while the other three treatment combinations increased cumulative P extracted only $6 \%-14 \%$. The greatest increases were seen in the $\mathrm{H}_{2} \mathrm{O}$ and $\mathrm{NaHCO}_{3}$ fractions, where the HP-HG treatment increased $\mathrm{P}$ concentrations $35.4 \%$ and $92 \%$ relative to the control, respectively. The lower three $\mathrm{P}$ rates increased the $\mathrm{H}_{2} \mathrm{O}-\mathrm{P} 39 \%$ - $49 \%$ and the $\mathrm{NaHCO}_{3}-\mathrm{P} 10 \%$ $38 \%$ relative to the control.

\section{CONCLUSIONS}

This study was conducted to see the effect of adding $P$ with gypsum on soil $\mathrm{P}$ forms and amounts as might occur when spreading spent gypsum from in-situ gypsum filters on adjacent fields. The $22.4 \mathrm{Mg} \cdot \mathrm{ha}^{-1}$ gypsum rate would be considered high and would likely result in other fertility issues (such as Mg leaching) due to excessive Ca application rates [24]. It appears that time after application and soil type would be significant factors in determining the availability of $\mathrm{P}$ added with gypsum. Moreover, total $\mathrm{P}$ rate, as a combination of gypsum rate and $\mathrm{P}$ saturation of that gypsum, had the most pronounced effect on soil $\mathrm{P}$ forms and concentrations. These findings indicate that spent gypsum from in-situ "ditch filters" could be applied at realistic rates to nearby fields without substantially changing the soil $\mathrm{P}$ concentrations and forms. The spent gypsum does not appear to be a viable fertilizer source of $P$ since it does not appear to be very labile, but it would not pose an environmental risk of highly soluble $\mathrm{P}$ available for loss in surface or sub- 
surface discharges. In fact, at $\mathrm{P}$ saturation levels that would be expected in actual spent gypsum, which would be much lower than those tested in this study, it is possible that the spent gypsum would continue to react with $\mathrm{P}$ in the soil solution in high $\mathrm{P}$ soils, reducing the availability of P for losses in runoff. However, this hypothesis should be evaluated in the future using actual residuals from prototype filters currently being evaluated. Furthermore, this study was conducted in a laboratory setting. The conditions in the laboratory differ significantly from what would be experienced in the field, most notably in biotic processes that would be tied to climatic variation in the field. Therefore, it would be prudent to duplicate this experiment in a long term field study.

\section{ACKNOWLEDGEMENTS}

This project was funded in part by a USDA-NRCS Conservation Innovation Grant (Award number NRCS 69-3A75-7-116). In addition, the authors wish to give special thanks to Dr. Bahram Momen for his guidance in statistical analysis of the data.

\section{REFERENCES}

[1] Obama, B. (2009) Executive order: Chesapeake Bay protection and restoration.

[2] CBPO (2009) Sources of phosphorus loads to the Bay. www.chesapeakebay.net/status_phosphorusloads.aspx?m enuitem=19801

[3] Pote, D.H., et al. (1996) Relating extractable soil phosphorus to phosphorus losses in Runoff. Soil Science Society of America Journal, 60, 855-859.

doi:10.2136/sssaj1996.03615995006000030025x

[4] Buda, A.R., et al. (2009) Effects of hydrology and field management on phosphorus transport in surface runoff. Journal of Environmental Quality, 38, 2273-2284. doi:10.2134/jeq2008.0501

[5] Sims, J.T., Simard, R.R. and Joern, B.C. (1998) Phosphorus loss in agricultural drainage: Historical perspective and current research. Journal of Environmental Quality, 27, 277-293. doi:10.2134/jeq1998.00472425002700020006x

[6] Kleinman, P.J.A., et al. (2007) Dynamics of phosphorus transfers from heavily manured coastal plain soils to drainage ditches. Journal of Soil and Water Conservation, 62, 225-235.

[7] Vadas, P.A., et al., (2007) Hydrology and groundwater nutrient concentrations in a ditch-drained agroecosystem. Journal of Soil and Water Conservation, 62, 178-188.

[8] Penn, C.J., et al. (2011) Trapping phosphorus in runoff with a phosphorus removal structure. Journal of Environment Quality, In Press.

[9] Leader, J.W., Dunne, E.J. and Reddy, K.R. (2008) Phosphorus sorbing materials: Sorption dynamics and physicochemical characteristics. Journal of Environmental Quality, 37, 174-181. doi:10.2134/jeq2007.0148
[10] Penn, C.J., et al. (2007) Removing dissolved phosphorus from drainage ditch water with phosphorus sorbing materials. Journal of Soil and Water Conservation, 62, 269276.

[11] Moore, P.A. and Miller, D.M. (1994) Decreasing phosphorus solubility in poultry litter with aluminum, calcium, and iron amendments. Journal of Environmental Quality, 23, 325-330. doi:10.2134/jeq1994.00472425002300020016x

[12] Penn, C.J., McGrath, J.M. and Bryant, R.B. (2010) Ditch drainage management for water quality improvement. In: Moore, M.T. and Kroger, R., Eds., Agricultural Drainage Ditches: Mitigation Wetlands for the 21st Century, Research Signpost, Kerala.

[13] Penn, C.J., et al. (2011) Use of industrial by-products to sorb and retain phosphorus. Communications in Soil Science and Plant Analysis, 42, 633-644. doi:10.1080/00103624.2011.550374

[14] Clark, R.B., Ritchey, K.D. and Baligar, V.C. (2001) Benefits and constraints for use of FGD products on agricultural land. Fuel, 80, 821-828. doi:10.1016/S0016-2361(00)00162-9

[15] Tan, K.H. (2005) Soil sampling, preparation, and analysis. Taylor \& Francis, New York.

[16] Hedley, M.J., White, R.E. and Nye, P.H. (1982) PlantInduced changes in the rhizosphere of rape (brassica napus var. emerald) seedlings. New Phytologist, 91, 45-56. doi:10.1111/j.1469-8137.1982.tb03291.x

[17] Warren, J.G., et al. (2008) The impact of alum addition on organic P transformations in poultry litter and litteramended soil. Journal of Environmental Quality, 37, 469-476. doi:10.2134/jeq2007.0239

[18] Martin, T.D., Creed, J.T. and Brockhoff, C.A. (1994) EPA method 200.2 sample preparation procedure for spectrochemical determination of total recoverable elements. US Environmental Protection Agency, Cincinnati.

[19] Tukey, J.W. (1953) The problem of multiple comparisons. Princeton University.

[20] Penn, C.J., et al. (2011) Alternative poultry litter storage for improved transportation and use as a soil amendment. Journal of Environmental Quality, 40, 233-241. doi:10.2134/jeq2010.0266

[21] Marsh, B. H. and J.H. Grove (1992) Surface and subsurface soil acidity: Soybean root response to sulfate-bearing spent lime. Soil Science Society of America Journal, 56, 1837-1842. doi:10.2136/sssaj1992.03615995005600060031x

[22] Sumner, M.E., et al. (1986) Amelioration of an acid soil profile through deep liming and surface application of gypsum1. Soil Science Society of America Journal, 50, 1254-1258. doi:10.2136/sssaj1986.03615995005000050034x

[23] Edgell, K. (1986) Method 3050: Acid digestion of sediments, sludges, and soils. USEPA, Washington.

[24] Penn, C.J. and Bryant, R.B. (2006) Application of phosphorus sorbing materials to streamside cattle loafing areas. Journal of Soil and Water Conservation, 61, 303310. 